\title{
Odontogenic Myxoma
}

National Cancer Institute

\section{Source}

National Cancer Institute. Odontogenic Myxoma. NCI Thesaurus. Code C7501.

An intraosseous odontogenic neoplasm with good prognosis, arising from the mandible and less frequently from the maxilla. It is characterized by the presence of stellate cells and abundant myxoid stroma formation. Small tumors may be cured with enucleation. Complete excision may be required for larger tumors. 